ISSN 0103-5150

Fisioter. Mov., Curitiba, v. 30, n. 3, p. 509-517, Jul./Sep. 2017

Licenciado sob uma Licença Creative Commons

DOI: http://dx.doi.org/10.1590/1980-5918.030.003.A009

\title{
Analysis of agreement between peak expiratory flow meters and comparison of reference values
}

\author{
Análise da concordância entre aparelhos de pico de fluxo \\ expiratório e comparação dos valores de referência
}

\author{
Daniela Ike $^{[a]}$, Claudia Eliane Cordeiro Bueno ${ }^{[b]}$, Jorge Cutlac Neto ${ }^{[c]}$, Bruna Varanda Pessoa-Santos ${ }^{[d]}$, \\ Mauricio Jamami ${ }^{[a] *}$
}

[a] Universidade Federal de São Carlos (UFSCar), São Carlos, SP, Brazil

[b] Faculdade Anhanguera de Piracicaba, Piracicaba, SP, Brazil

[c] Universidade Federal do Triângulo Mineiro (UFTM), Uberaba, MG, Brazil

[d] Universidade Sagrado Coração (USC), Bauru, SP, Brazil

\begin{abstract}
Introduction: The peak expiratory flow (PEF) is a practical method that evaluates the caliber of the proximal airways. The ease in handling and the low cost of portable PEF meters made their use frequent. However, few studies have examined the correlation between the different equipment and compared their reference values. Objective: Analyze the correlation of three portable meters of PEF and check if the reference values are applicable in the studied population. Methods: 168 healthy individuals, of both genders, ranging in age from 20 to 80 years, had their PEF measured in Mini-Wright $₫$, Assess $₫$ and AirZone $₫$ and the values obtained were compared to those predicted by Leiner et al. (1963) and Nunn and Gregg (1989). Statistical analysis was performed by the Kolmogorov-Smirnov tests, ANOVA, Wilcoxon test, Spearman correlation and analysis of agreement of Bland-Altman ( $p<0.05)$. Results: There was significant difference in the values of PEF obtained between the Mini-Wright $\AA$ and Assess ${ }^{\circledR}$ meters in both genders, between the AirZone ${ }^{\circledR}$ and
\end{abstract}

\footnotetext{
* DI: PhD, e-mail: daniela.ike@gmail.com

CECB: BS, e-mail: claudiacordeirobueno@gmail.com

JCN: BS, e-mail: jcutlac@hotmail.com

BVPS: PhD, e-mail: brunavpessoa@gmail.com

MJ: PhD, e-mail: jamami@ufscar.br
} 
Assess $₫$ only in men and between the Mini-Wright ${ }^{\circledR}$ and AirZone $₫$ only in women. The predicted values in the three meters have overestimated the obtained in both genders; there was no correlation between the values obtained from three meters due to the great variation of agreement limits and large interindividual variation. Conclusion: The values obtained in the three meters are not interchangeable and the predicted values were unsuitable for the sample.

Keywords: Peak Expiratory Flow. Reference Values. Respiratory Function Tests. Physiotherapy.

\title{
Resumo
}

\begin{abstract}
Introdução: $O$ pico de fluxo expiratório (PFE) é um método acessivel que avalia o calibre das vias aéreas proximais. A facilidade no manuseio e o baixo custo dos medidores portáteis de PFE tornaram seu uso frequente, entretanto, poucos estudos analisaram a concordância entre os diferentes equipamentos e compararam seus valores de referência. Objetivo: Analisar a concordância de três medidores portáteis de PFE e verificar se os valores de referência são aplicáveis na população estudada. Métodos: 168 indivíduos saudáveis, de ambos os gêneros, na faixa etária de 20 a 80 anos, realizaram medidas de PFE nos aparelhos Mini-Wright ${ }^{\circledR}$, Assess $®$ e AirZone ${ }^{\circledR}$ e comparou-se os valores obtidos aos previstos por Leiner et al. (1963) e Nunn e Gregg (1989). A análise estatística foi realizada pelos testes Kolmogorov-Smirnov, ANOVA, teste de Wilcoxon, correlação de Spearman e análise de concordância de Bland-Altman $(p<0,05)$. Resultados: Constatou-se diferença significativa nos valores de PFE obt idos entre os medidores Mini-Wright ${ }^{\circledR}$ e Assess $\AA$ em ambos os gêneros, entre o AirZone $₫$ e o Assess $₫$ apenas nos homens e entre o Mini-Wright $\left(\right.$ e o AirZone ${ }^{\circledR}$ somente nas mulheres, sendo que os valores previstos nos três aparelhos superestimaram os obtidos em ambos os gêneros; não se verificou concordância entre os valores obtidos dos três medidores devido à grande variação dos limites de concordância e grande variação interindividual. Conclusão: Os valores obtidos nos três medidores não são intercambiáveis e os valores previstos se mostraram inadequados para a amostra estudada.
\end{abstract}

Palavras-chave: Pico do Fluxo Expiratório. Valores de Referência. Testes de Função Respiratória.

Fisioterapia.

\section{Introduction}

Peak expiratory flow (PEF) is an instantaneous air stream, approximately $20 \%$ of the forced vital capacity, corresponding mainly to the bronchial airflow, being too small the contribution of the small airways. The PEF, which has important effort-dependent component, is determined by the volume and elasticity of the lungs, by dimension and compliance of central intrathoracic airways and the strength and speed of contraction of expiratory muscles (1).

The PEF evaluates the strength and speed of the air inside the lungs, detects the narrowing of the airways and can be useful to monitor asthma, classify its severity and evaluate the response to treatment $(2,3)$.

Compared to the spirometry, PEF requires only the completion of maximum inspiration followed by maximum and forced expiration, and does not require a lot of training and experience to be handled (4). Although not recommended for the diagnosis of airflow obstruction $(5,6)$, recent studies suggest that measures of PEF can be a handy method of screening and initial identification of severe cases of chronic obstructive pulmonary disease (COPD) for subsequent confirmation by spirometry $(7,8)$.

Currently, the portable PEF meters have been widely used due to its low cost and ease of handling, however there is a wide variety of equipment and few studies examining the correlation between the different devices. Much of the literature studies compared the values obtained from different meters of PEF with values obtained by spirometry and noted significant differences $(9,10)$ but, according to Pesola et al. (11), the predicted values should not 
be derived from spirometry, because both methods are not comparable.

For appropriate interpretation of results, it is necessary to use reference values that are representative of the studied population, since such values differ from one population to another, or even between different regions of a country, considering anthropometric differences, cultural habits, socioeconomic levels, climatic conditions and nutritional status (2).

Generally, portable equipment come with a specific reference equation, which often does not correspond to the studied population. In the case of meters used in this study, the equations were established from North American (12) and European populations (13). Studies comparing the values obtained from different populations $(2,4,14)$ to those predicted by the equation of Nunn and Gregg (13) found significant difference and the values obtained were lower than those predicted by these authors.

Considering that the measure of the PEF is useful in respiratory physiotherapy clinical practice, the choice of equipment, as well as of appropriate reference values, is essential for the correct interpretation of the results. However, few studies have compared the correlation between the different equipment and evaluated the applicability of the equations of Leiner et al. (12) and (13) and Gregg Nunn in the Brazilian population.

Therefore, the aim of this study was to compare the values obtained and analyze the agreement of three portable PEF meters, beyond checks if the reference values that accompany these devices are applicable for a sample of adults from three cities in the Southeast region of Brazil. The hypothesis is that there are differences between the values obtained with three meters of PEF and also in the comparison of values obtained with those predicted by the equations, since they were derived from populations with characteristics that are different from the Brazilian population.

\section{Methods}

Sample

258 healthy individuals were evaluated, of both genders, ranging in age from 20 to 80 years, from Southeast of Brazil, including three cities: São Paulo (SP), Piracicaba (SP), and Uberaba (MG).
The criteria for inclusion in the study were: non or former smokers (10 years of smoking cessation); sedentary or insufficiently active (not performed any kind of exercise at least three times a week for 20 minutes, according to recommendations from the American College of Sports Medicine (15); body mass index $(\mathrm{BMI})<30 \mathrm{~kg} / \mathrm{m}^{2}$; absence of neurological diseases, respiratory and/or temporomandibular joint disorders (information collected according to the account of the patients during the evaluation) that could affect the values of PEF; absence of inflammation of the upper airways in the last 14 days; those who perform properly the maneuvers for getting the values of PEF.

The volunteers were invited to participate in the study through outreach in posters, radio and internet, and the researchers performed the evaluation "in loco" at events and health fairs. All volunteers received orientation and explanation regarding the procedures of the study and signed an Informed Consent Form, in accordance with determinations from the Resolution 466/12, from the National Health Council, after approval of the Ethics on Research Committee of the institution (statement 13.222/2012).

\section{Experimental Procedure}

Initially, an assessment was performed to collect personal data, anthropometric data (body mass, height, body mass index-BMI), life habits, personal and family pathological antecedents. Later, the volunteers were instructed on the handling of the meters and measures of PEF were made at random (the order of devices was determined by the examiner drawing envelopes), in Mini-Wright ${ }^{\circledR}$, Assess $^{\circledR}$ and AirZone ${ }^{\circledR}$, new and factory-calibrated devices, respecting the limit of 200 blows on each device (16). With the volunteer standing (17) and with the head positioned on the midline, without the use of nasal clip (18), was requested a maximum forced and fast expiration assuming maximum lung volume (Total lung capacity), advising him not to flex the neck or obstruct the nozzle with the tongue during forced expiration (19). During the maneuver, the volunteers received a standardized verbal command from a trained researcher. A pause of 30 seconds between each measure was given to prevent the respiratory muscle fatigue (19). Were considered three reproducible maneuvers, however, if the two highest values of three measures presented difference greater than 40 
$\mathrm{L} / \mathrm{min}$, two additional measures were carried out, being five maneuvers the established limit. The highest value obtained was registered for data analysis (19).

The values obtained in each one of the devices were compared to those predicted in accordance with the reference table that accompanies each equipment: Mini-Wright ${ }^{\circledR}(12)$, AirZone $^{\circledR}(12)$, Assess $^{\circledR}(13)$.

\section{Statistical analysis}

First, the Kolmogorov-Smirnov test for normality were applied. Then, the ANOVA test for repeated measures with post hoc Bonferroni correction was used for comparison of values obtained in different equipments; and, for comparison of the values obtained with those predicted, the Wilcoxon test was applied, as well as the Spearman correlation. The programs used were SPSS version 17.0 (SPSS Inc., Chicago, IL, USA), and the Graph Pad Instat ${ }^{\circledR}$, version 3.5 (Graph Pad Software Inc.).

The graphic analysis of Bland-Altman was used to determine the agreement between the different equipment of PEF (20). The program used was the MedCalc, version 9.4.1.0 (MedCalc, Mariakerke, Belgium). It was considered a significance level of $5 \%(p<0.05)$.

\section{Results}

258 individuals were evaluated, and 90 were excluded because they did not meet the inclusion criteria of the study. The flowchart of the participants of the study is shown in Figure 1.

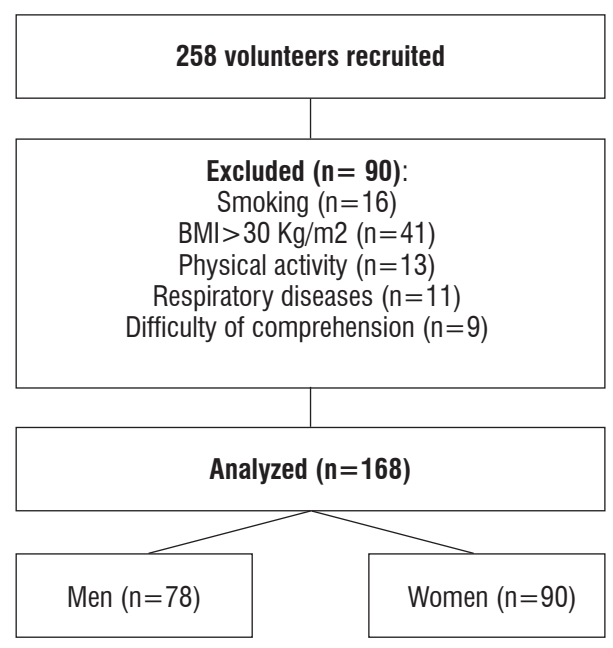

Figure 1 - Flowchart of the participants of the study.
Demographic and anthropometric characteristics of individuals evaluated are separated by gender and arranged in Table 1.

Table 1 - Demographic and anthropometric characteristics of the sample

\begin{tabular}{ccc}
\hline Variable & Women $(\mathrm{n}=\mathbf{9 0})$ & Men $(\mathrm{n}=\mathbf{7 8})$ \\
\hline Age (years) & $44.8 \pm 19.0$ & $42.1 \pm 18.9$ \\
$\begin{array}{c}\text { Corporal Mass } \\
(\mathrm{kg})\end{array}$ & $62 \pm 9.8$ & $74.8 \pm 12.1$ \\
Height $(\mathrm{m})$ & $1.6 \pm 0.1$ & $1.7 \pm 0.1$ \\
BMl $(\mathrm{Kg} / \mathrm{m} 2)$ & $24.2 \pm 3.6$ & $24.8 \pm 3.0$ \\
\hline
\end{tabular}

Note: Data presented as mean \pm Standard Deviation. BMI: Body mass index; n: number of individuals.

The analysis between the values obtained in PEF observed significant difference between values of PEF obtained by Mini-Wright ${ }^{\circledR}$ and Assess ${ }^{\circledR}$ in both genders, between the obtained by AirZone ${ }^{\circledR}$ and Assess ${ }^{\circledR}$ only in men and among those obtained by Mini-Wright ${ }^{\circledR}$ and AirZone ${ }^{\circledR}$ only in women (Table 2). It was also found that the values of PEF predicted in the three devices were found to be significantly higher than the values of PEF obtained in both genders (Table 2).

Moderate significant correlations were found between the values of PEF obtained and predicted in both genders (Table 3). We found strong correlations between the values of PEF obtained in MiniWright ${ }^{\circledR}$ device with the Assess ${ }^{\circledR}(r=0.913)$ and with the AirZone ${ }^{\circledR}(r=0.916)$ and among those obtained by Assess ${ }^{\circledR}$ and AirZone ${ }^{\circledR}(r=0.934)$; and among those obtained by Mini-Wright ${ }^{\circledR}$ with the Assess ${ }^{\circledR}$ (r $=0.838)$ and with the AirZone ${ }^{\circledR}(r=0.908)$ and among those obtained by Assess ${ }^{\circledR}$ and AirZone ${ }^{\circledR}(r=0.813)$ in women and men, respectively.

As noted in Figure 2, it was not possible to see agreement between the values of PEF obtained in all three analyses, since, the average of difference between the averages with (1.96) standard deviation between Mini-Wright ${ }^{\circledR}$, AirZone $^{\circledR}$ and Assess ${ }^{\circledR}$ were $1.6(25.4 \mathrm{~L} / \mathrm{min}) ; 11.2(30.2 \mathrm{~L} / \mathrm{min})$ and 9.6 $(60.4 \mathrm{~L} / \mathrm{min})$ for women, and $-22.6(58.5 \mathrm{~L} / \mathrm{min}) ; 8.5$ (38.7 L/min) and $31.0(54.8 \mathrm{l} / \mathrm{min})$ for men, respectively, with great variation in the agreement limits and large interindividual variation, where the values of PEF dispersed between +2 standard deviations. The expected ideal result would be the values close to the midline (average of the difference between the averages of the PEF meters). 

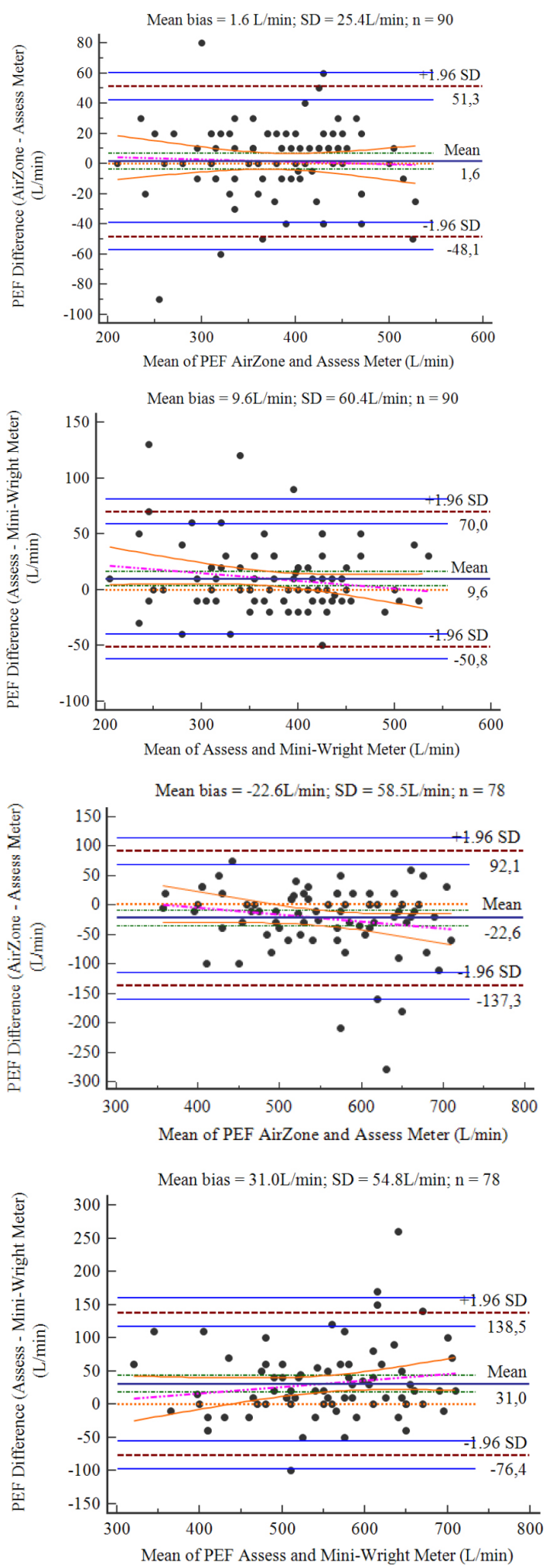

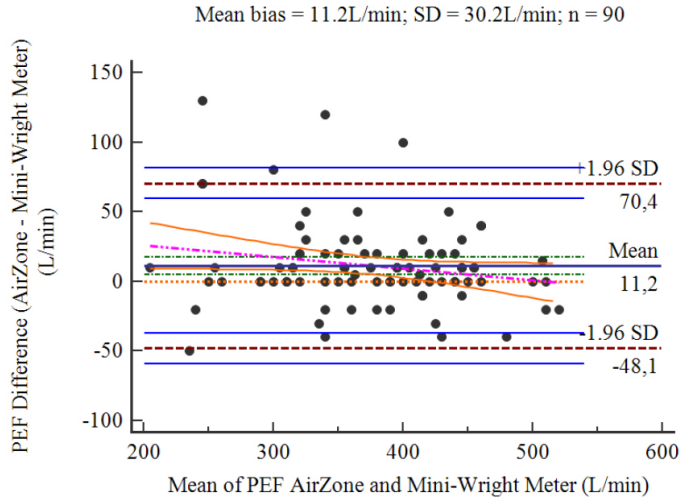

$2 A$

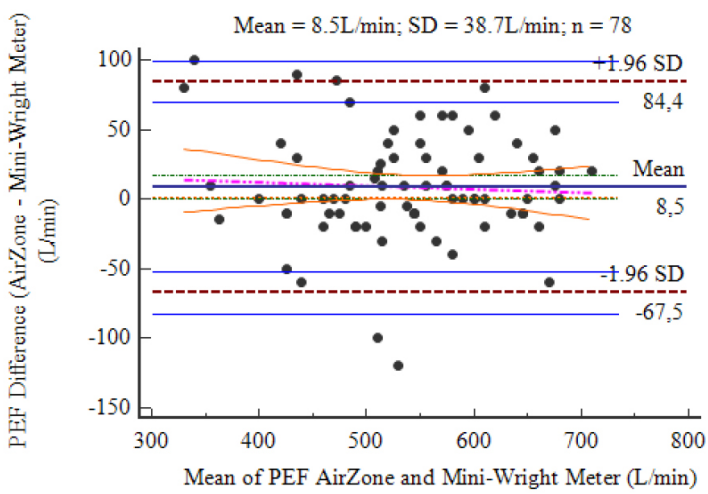

2B

Figure 2 - Agreement between obtained values PEF by the AirZone ${ }^{\circledR}$, Assess ${ }^{\circledR}$ and Mini Wright ${ }^{\circledR}$ meters in women $(n=90)(2 A)$ and in men $(\mathrm{n}=78)(2 \mathrm{~B})$, according to Bland-Altman analysis.

PEF: Peak of expiratory flow; Bias: mean of the difference between means; SD: Standard Deviation; $n=$ number of individuals; $(+1.96 \mathrm{SD})=95 \%$ confidence interval (CI); Orange Line: Regression line of the PEF difference versus means; Blue Line: Line drawn for the $95 \%$ confidence interval of the limits of agreement; Dotted Brown Line: Line drawn for the $95 \%$ confidence interval of the mean differences. 
Table 2 - Obtained and predicted PEF values in the Mini-Wright ${ }^{\circledR}$, Assess $^{\circledR}$ and AirZone ${ }^{\circledR}$ in the evaluated individuals

\begin{tabular}{|c|c|c|c|c|c|c|}
\hline Variables & $\begin{array}{c}\text { Mini-Wright }{ }^{\circledR} \\
\text { (L/min) }\end{array}$ & $\begin{array}{l}\text { AirZone }^{\circledR} \\
\text { (L/min) }\end{array}$ & $\begin{array}{l}\text { Assess }^{\circledR} \\
\text { (L/min) }\end{array}$ & & & \\
\hline & Obtained & Predicted & Obtained & Predicted & Obtained & Predicted \\
\hline Women $(n=90)$ & $371.4 \pm 75.3$ & $424.2 \pm 38.3 * *$ & & & & \\
\hline $576 \pm 65.6$ ** & $382.6 \pm 69.4 \phi$ & $424.3 \pm 38.3$ ** & $381 \pm 70.4^{*}$ & $\underset{* \star}{455.4 \pm 33.2}$ & & \\
\hline Men $(n=78)$ & $535.2 \pm 91.2$ & & $543.6 \pm 89.1$ & $\underset{\star \star \star}{576.2 \pm 65.6}$ & $566.2 \pm 99.5^{\star} ¥$ & $\underset{* \star}{595.1 \pm 38.8}$ \\
\hline
\end{tabular}

Note: Data expressed in mean \pm Standard Deviation. $\mathrm{n}=$ number of indivíduals. Wilcoxon Test $={ }^{* *}$ Obtained PEF $\neq$ Predicted PEF. ANOVA repeated measures with post hoc Bonferroni correction: * $=$ Mini-Wright ${ }^{\circledR}$ obtained $\neq$ Assess $^{\circledast}$ obtained; $¥=$ AirZone $^{\circledast}$ obtained $\neq$ Assess $^{\circledast}$ obtained; $\phi=$ Mini-Wright ${ }^{\circledR}$ obtained $\neq$ AirZone ${ }^{\circledast}$ obtained.

Table 3 - Spearman correlation between the obtained and predicted values in the Mini-Wright ${ }^{\circledR}$, Assess ${ }^{\circledR}$ and AirZone ${ }^{\circledR}$ meters

\begin{tabular}{ccccc}
\hline \multicolumn{5}{c}{ Predicted Values } \\
\hline \multicolumn{4}{c}{ Women } & \multicolumn{2}{c}{ Men } \\
\hline $\begin{array}{c}\text { Obtained } \\
\text { Values }\end{array}$ & $r$ & $p$ & $r$ & $p$ \\
\hline Mini-Wright $^{\circledR}$ & 0.467 & $<0.01$ & 0.432 & $<0.01$ \\
Assess $^{\circledR}$ & 0.407 & $<0.01$ & 0.467 & $<0.01$ \\
AirZone $^{\circledR}$ & 0.457 & $<0.01$ & 0.519 & $<0.01$ \\
\hline
\end{tabular}

\section{Discussion}

According to the guidelines for pulmonary function tests (18), the various brands of PEF generally differ in the results observed for the same individual, and often exhibit non-linearity on the meters (21). In this study we compared the values obtained from three different devices of PEF and significant difference was observed between the Mini-Wright ${ }^{\circledR}$ and Assess ${ }^{\circledR}$ meters in both genders, between the AirZone ${ }^{\circledR}$ and Assess ${ }^{\circledR}$ only in men, and between the Mini-Wright ${ }^{\circledR}$ and AirZone ${ }^{\circledR}$ only in women.

These differences can be attributed to the fact that Mini-Wright ${ }^{\circledR}$ meter presented the lowest values of PEF in men and women, and due to men having achieved high values of PEF, especially on Assess ${ }^{\circledR}$ meter because although they were insufficiently active, some exceeded the AirZone ${ }^{\circledR}$ range of $720 \mathrm{~L} / \mathrm{min}$, consisting a limiting factor in the use of this meter, that differs from the scale of most adult meters $(100$ to $850 \mathrm{~L} / \mathrm{min}$ ). It should be noted, in this way, the importance of the choice of standardized equipment and scales appropriate to the population being studied.

The existing studies in the literature have compared the different meters of PEF to values predicted by spirometry and observed contradictory results $(10,22,23)$. Some authors have found that the measurements obtained by the portable device MiniWright ${ }^{\circledR}$ are more reliable than those obtained by other types of equipments (18, 24 - 27). However, in the study of Pesola et al. (11) it was observed that the values obtained through the Mini-Wright ${ }^{\circledR}$ were much higher than predicted by spirometry in healthy individuals, suggesting that the predicted values should not be derived from the spirometry, since both methods are not comparable.

The study by Takara et al. (9), when comparing the values obtained with the Galemed ${ }^{\circledR}$, Air Zone $^{\circledR}$, Personal Best ${ }^{\circledR}$ and Vitalograph ${ }^{\circledR}$ meters concluded that both the Galemed ${ }^{\circledR}$ and the Air Zone ${ }^{\circledR}$ provided significantly different results, and have great variation in its limits of agreement. And Kulnik et al. (28) compared the accuracy of four portable meters (Mini-Wright $^{\circledR}$, Assess $^{\circledR}$, SpiroUSB ${ }^{\circledR}$ and Microlab spirometers) concluding that depending on the measuring instrument used, absolute values of peak cough flow recorded in literature should not be compared directly.

In our results, although strong and significant correlations were observed between the values of PEF obtained, it has not been possible to observe agreement between them, according to the graphic analysis of Bland-Altman (Figure 2), due to the great variation of agreement limits and large interindividual 
variation, which suggests that a patient should always be evaluated with the same model of device and that there should be difference in predictive equations according to the meter.

In addition, when comparing the values obtained to those predicted in each meter, we found an overestimation of Leiner et al. (12) (Mini-Wright ${ }^{\circledR}$ and AirZone ${ }^{\circledR}$ ) and Nunn and Gregg (13) (Assess ${ }^{\circledR}$ ) in both genders, which reinforces the findings of Menezes et al. (16) that evaluated adults over 40 years-old, residents in the city of Pelotas (RS), and also found it difficult to compare their values of PEF with the study done by Nunn and Gregg (13), because the found data was lower than those parameters recommended by the English authors.

The same result was found in the study of Kodgule et al. (2), which compared the values obtained from the Indian population to equations of Nunn and Gregg (13), for Europeans, and NHANES III (29), for Caucasian Americans. The values obtained were 30 and $20 \%$ lower, respectively. In the study of Paes et al. (30) that compared the reference values according to different authors with the values obtained from a sample of the population of São Carlos and found that the values predicted in 1963 (12), 1989 (13) and 2001 (31), in the age group of 20-30 years for the male, overestimated the values obtained.

These findings show that the predictive equations must be representative of the population we want to assess and, since the variables that most commonly determine the derivation of the equations of PEF are gender, age and height and whereas the equations that accompany this study evaluated meters were predicted for European (12) and North American (13) population, it can be said that the anthropometric differences between these populations and our sample may have influenced the values of PEF.

Considering that even though the studied sample was healthy, most of the volunteers reached, on average, only $85 \%$ of predicted, it is expected that individuals with pulmonary dysfunctions would have a performance below that percentage, which indicates the inconsistency of these equations, as they may overestimate the severity of the clinical condition, leading to unnecessary intervention.

For the Brazilian population, the only proposal of equation for adults is from the study by Menezes et al. (14), which assessed individuals over 40 years of age in south of Brazil; other studies have emerged later in several Brazilian cities, however the predictive equations included only children and teenagers (32, 33).

According to Kodgule et al. (2), even between different regions of a country there are also differences in the values of PEF. Indians of the South region showed lower values of PEF if compared to the northern region, probably due to differences of genetic, climatic, and nutritional characteristics between these populations, suggesting the use of regional equations in clinical practice.

These results show the importance of proper choice of standardized equipment with appropriate scales and reference values according to the studied population, since the evaluation of peak expiratory flow is widely used in clinical practice of physiotherapy and also in the routine of asthmatic patients to control crisis. Also highlights the need for future multicenter studies, involving several regions of Brazil, with the purpose of developing reference values of $\mathrm{PEF}$ that represent the Brazilian population.

The evaluation of individuals of some cities of a single region in Brazil (Southeast) and the impossibility of performing spirometry tests for assessment of pulmonary function of the sample studied are limitations of the present study.

\section{Conclusion}

According to the obtained results, it is concluded that the Mini-Wright ${ }^{\circledR}$, Assess $^{\circledR}$ and AirZone ${ }^{\circledR}$ meters are not interchangeable in both genders, and the equations proposed by Leiner et al. (12) and Nunn and Gregg (13) were not able to predict the values obtained from the sample.

\section{References}

1. Lebowitz MD, Sherrill DL, Kaltenborn W, Burrows B. Peak expiratory flow from maximum expiratory flow volume curves in a community population: cross-sectional and longitudinal analyses. Eur Respir J Suppl. 1997;24:29S-38S.

2. Kodgule RR, Singh V, Dhar R, Saicharan BG, Madas SJ, Gogtay JA, et al. Reference values for peak expiratory flow in Indian adult population using a European Union scale peak flow meter. J Postgrad Med. 2014;60(2):123-9. 
3. Manjunath CB, Kotinatot SC, Manjunatha B. Peak expiratory flow rate in healthy rural school going children (5-16 years) of Bellur region for construction of normogram. J Clin Diagn Res. 2013;7(12);2844-6.

4. Tian J, Zhou Y, Cui J, Wang D, Wang X, Hu G, et al. Peak expiratory flow as a screening tool to detect airflow obstruction in a primary health care setting. Int J Tuberc Lung Dis. 2012;16(5):674-80.

5. Aggarwal AN, Gupta D, Jindal SK. The relationship between FEV1 and peak expiratory flow in patients with airways obstruction is poor. Chest. 2006;130:1454-61.

6. Hegewald MJ, Lefor MJ, Jensen RL, Crapo RO, Kritchevsky SB, Haggerty CL, et al. Peak expiratory flow is not a quality indicator for spirometry: peak expiratory flow variability and FEV1 are poorly correlated in an elderly population. Chest. 2007; 131:1494-9.

7. Jithoo A, Enright PL, Burney P, Buist AS, Bateman ED, Tan WC, et al. Case-finding options for COPD: Results from the burden of obstructive lung disease study. Eur Respir J. 2013;41(3):548-55.

8. Perez-Padilla R, Vollmer W, Vázquez-García J, Enright P, Menezes A, Buist A, et al. Can a normal peak expiratory flow exclude severe chronic obstructive pulmonary disease? Int J Tuberc Lung Dis. 2009;13(3):387-93.

9. Takara GN, Ruas G, Pessoa BV, Jamami LK, Di Lorenzo VAP, Jamami M. Comparison of five portable peak flow meters. Clinics 2010; 65(5):469-74.

10. Pothirat C, Chaiwong W, Phetsuk N, Liwsrisakun C, Bumroongkit C, Deesomchok A, et al. Peak expiratory flow rate as a surrogate for forced expiratory volume in 1 second in COPD severity classification in Thailand. Int J Chron Obstruct Pulmon Dis. 2015; 10(1):1213-18.

11. Pesola GR, O’Donnell P, Pesola GR, Chinchilli VM, Saari AF. Peak expiratory flow in normals: comparison of the mini Wright versus spirometric predicted peak flows. J Asthma. 2009;46(8):845-8.

12. Leiner GC, Abramowitz S, Small MJ, Stenby VB, Lewis WA. Expiratory peak flow rate. Standard values for normal subjects. Use a clinical test of ventilatory function. Am Rev Respir Dis. 1963;88:644-51.

13. Nunn AJ, Gregg I. New regression equations for predicting peak expiratory flow in adults. BMJ. 1989;298:1068-70.
14. Menezes AM, Victoria CG, Horta BL, Rigatto M. Valores de referência para o pico de fluxo expiratório em adultos acima de 40 anos, Pelotas, RS. J Pneumol. 1995; 21(2):119-22.

15. Garber CE, Blissmer B, Deschenes MR, Franklin BA, Lamonte MJ, Lee IM, et al. American College of Sports Medicine. American College of Sports Medicine position stand. Quantity and quality of exercise for developing and maintaining cardiorespiratory, musculoskeletal, and neuromotor fitness in apparently healthy adults: guidance for prescribing exercise. Med Sci Sport Exerc. 2011;43(7):1334-59.

16. Shapiro SM, Hendler JM, Ogirala RG, Aldrich TK, Shapiro MB. An evaluation of the accuracy of Assess and Mini-Wright peak flow meters. Chest. 1991;99:358-62.

17. McCoy EK, Thomas JL, Sowell RS, George C, Finch CK, Tolley EA, et al. An evaluation of peak expiratory flow monitoring: a comparison of sitting versus standing measurements. J Am Board Fam Med. 2010; 23(2):166-70.

18. Sociedade Brasileira de Pneumologia e Tisiologia. Diretrizes para testes de função pulmonar. J Pneumol. 2002;28(Supl. 3):1-238.

19. Quanjer PH, Lebowitz MD, Gregg I, Miller MR, Pedersen OF. Peak expiratory flow: conclusions and recommendations of a Working Party of the European Respiratory Society. Eur Respir J. 1997;10(24):2-8 (Supl).

20. Bland JM, Altman DG. Statistical methods for assessing agreement between two methods of clinical measurement. Lancet. 1986;1:307-10.

21. Ayres JG, Turpin PJ. Measurement, recording and analysis of peak flow records. In: Peak flow measurement. Chapman \& Hall Medical. 1997;13-32.

22. Fonseca ACCF, Fonseca MTM, Rodrigues MESM, Lasmar LMLBF, Camargos PAM. Pico de fluxo expiratório no acompanhamento de crianças asmáticas. J Pediatr. 2006;82(6):465-9.

23. Rosa FW, Sales NBB, Batista AKMS, Camelier AA. Comparação entre dois dispositivos mensuradores de pico de fluxo expiratório em jovens sadios. Rev Pesq em Fisiot. 2012;2(2):93-106.

24. Pedersen OF, Rasmussen TR, Omland O, Sigsgaard T, Quanjer PH, Miller MR. Peak expiratory flow and the resistance of the Mini-Wright peak flow meter. Eur Respir J. 1996; 9(4):828-33. 
25. Miller MR, Pedersen OF. The Peak Flow Working Group: The characteristics and calibration of devices for recording peak expiratory flow. Eur Respir J. 1997; $10(24): 17 \mathrm{~S}-22 \mathrm{~S}$.

26. Folgering H, Brink W, Heeswijk O, Heerwarden C. Eleven peak flow meters: A clinical evaluation. Eur Respir J. 1998;11(1):188-93.

27. Ruchkys VC, Dias RM, Sakurai E, Camargos PAM. Acurácia de medidores de pico de fluxo expiratório (peak flow) da marca Mini-Wright. Jornal de Ped. $2000 ; 76(6): 447-52$.

28. Kulnik ST, MacBean V, Birring SS, Moxham J, Rafferty GF, Kalra L. Accuracy of portable devices in measuring peak cough flow. Physiol Meas. 2015;36(2):243-57.

29. Hankinson JL, Odencrantz JR, Fedan KB. Spirometric reference values from a sample of the general US population. Am J Respir Crit Care Med. 1999;159:179-87.

30. Paes CS, Pessoa BV, Jamami M, Di Lorenzo VAP, Marrara KT. Comparação de valores de PFE em uma amostra da população da cidade de São Carlos, São Paulo, com valores de referência. J Bras Pneumol. 2009;35(2):1-6.
31. Abascal CME, Grau AR, La Rosa DA. Valores normales de flujo expiratório forzado em la población de Ranchuelo. Rev Cuba Med. 2001;40(4):243-52.

32. Boaventura CM, Amuy FF, Franco JH, Sgarbi ME, Matos LB, Matos LB. Valores de referência de medidas de pico de fluxo expiratório máximo em escolares. Arq Med ABC. 2007;32(Supl. 2):S30-4.

33. Fritscher CC, Martins FP, Kahan F. Pico de fluxo expiratório em escolas de Porto Alegre, RS. Rev Med PUC-RS. 1996;6(4):19-23.

Received in: 12/06/2015

Recebido em: 06/12/2015

Approved in: $11 / 16 / 2016$

Aprovado em: 16/11/2016 
